46 (1) | 2017

La orfebrería en los Andes en la época inca (siglos XV$\mathrm{XVI})$

\title{
Las estatuillas incas del musée du quai Branly - Jacques Chirac: variedad tipológica y cronología de las producciones
}

Les figurines incas du musée du quai Branly - Jacques Chirac : variété

typologique et chronologie des productions

The Inca figurines of the musée du quai Branly - Jacques Chirac: typological

variety and production chronology

Paz Núñez-Regueiro, Christophe Moulherat y Maria Filomena Guerra

\section{(2) OpenEdition}

Journals

Edición electrónica

URL: http://journals.openedition.org/bifea/8198

DOI: 10.4000/bifea.8198

ISSN: 2076-5827

Editor

Institut Français d'Études Andines

Edición impresa

Fecha de publicación: 1 abril 2017

Paginación: 193-219

ISSN: 0303-7495

Referencia electrónica

Paz Núñez-Regueiro, Christophe Moulherat y Maria Filomena Guerra, «Las estatuillas incas del

musée du quai Branly - Jacques Chirac: variedad tipológica y cronología de las producciones », Bulletin de l'Institut français d'études andines [En línea], 46 (1) | 2017, Publicado el 08 abril 2017, consultado el 05 noviembre 2020. URL : http://journals.openedition.org/bifea/8198; DOI : https://doi.org/10.4000/ bifea.8198

\section{(c)}

Les contenus du Bulletin de l'Institut français d'études andines sont mis à disposition selon les termes de la licence Creative Commons Attribution - Pas d'Utilisation Commerciale - Pas de Modification 4.0 International. 


\title{
Las estatuillas incas del musée du quai Branly - Jacques Chirac: variedad tipológica y cronología de las producciones
}

\author{
Paz Núñez-Regueiro* \\ Christophe Moulherat** \\ Maria Filomena Guerra***
}

\section{Resumen}

La colección de orfebrería inca del musée du quai Branly - Jacques Chirac (París) fue constituida en el siglo XIX como resultado de la recolección o de las compras realizadas por diversos viajeros y coleccionistas. Esta se compone de estatuillas en miniatura de oro, plata o cobre, cuya variedad formal, estilística y material interroga tanto su atribución cultural como la autenticidad de ciertos ejemplares. El estudio contextual, así como el análisis de su variedad tipológica, tecnológica y de sus aleaciones, proporciona información sobre la producción orfebre de esas piezas durante el Incanato y en los períodos posteriores a la conquista española, del siglo XVI al siglo XIX.

Palabras clave: estatuillas, miniaturas, cultura inca, orfebrería, aleaciones de plata y de oro, musée du quai Branly - Jacques Chirac

* Unidad Patrimonial «Américas», Departamento de Patrimonio y Colecciones, musée du quai Branly - Jacques Chirac, 222 rue de I'Université, 75007 París cedex 07, Francia. E-mail: pnr@ quaibranly.fr

** Polo Conservación-Restauración, Departamento de Patrimonio y Colecciones, musée du quai Branly - Jacques Chirac, 222 rue de I'Université, 75007 París cedex 07, Francia. E-mail: christophe. moulherat@gmail.com

${ }^{* * *}$ CNRS, ArchAm-UMR 8096, Maison Archéologie \& Ethnologie, 21 allée de I'Université, 92023 Nanterre, France. E-mail: maria.guerra@cnrs.fr 


\title{
Les figurines incas du musée du quai Branly - Jacques Chirac : variété typologique et chronologie des productions
}

\section{Résumé}

La collection d'orfèvrerie inca conservée au musée du quai Branly - Jacques Chirac (Paris) fut constituée au XIX siècle comme fruit de la collecte et des achats réalisés par voyageurs et collectionneurs. Elle se compose de figurines miniatures en or, argent ou cuivre, dont la diversité formelle, stylistique et matérielle renvoie à l'attribution culturelle et à l'authenticité de certains spécimens. L'étude contextuelle, ainsi que l'analyse de la variété typologique, technologique et des alliages nous fournit des informations sur la production orfèvre de ces pièces produites à la période inca, puis aux périodes ayant succédé à la conquête espagnole, du XVI ${ }^{\mathrm{e}}$ au XIXe siècle.

Mots-clés : figurines, miniatures, culture inca, orfèvrerie, alliages d'argent et d'or, musée du quai Branly - Jacques Chirac

\section{The Inca figurines of the musée du quai Branly - Jacques Chirac: typological variety and production chronology}

\begin{abstract}
The Inca metalwork collection held at the Musée du quai Branly - Jacques Chirac (Paris) developed in the 19th century through the activities of varied travelers and collectors. The formal, stylistic and material variety of the miniature figurines in gold, silver and copper raises questions about their cultural attribution and in some cases their authenticity. Their contextual study, as well as the analysis of their typological, technological variety and material composition, provide us with information on the production of these figurines during the Inca period, and during the periods following the Spanish conquest, from the 16 th to the 19th century.
\end{abstract}

Keywords: figurines, miniatures, Inca culture, silver and goldwork, gold and silver alloys, musée du quai Branly - Jacques Chirac

\section{INTRODUCCIÓN}

Los orfebres incas produjeron estatuillas de seres humanos y camélidos que se empleaban en rituales de ofrenda vinculados a los altos representantes del Imperio inca (1450-1532). Al ocurrir la conquista española en el siglo XVI, estas fueron fundidas junto con otras tantas riquezas orfebres; hoy se conoce parcialmente su importancia numérica y su variedad estilística. Algunos hallazgos fortuitos y las excavaciones arqueológicas han revelado la variedad de esta producción de oro, plata o cobre, que respeta sin embargo cánones estilísticos estandarizados.

Las estatuillas antropomorfas miden en general menos de diez centímetros. Se las representa de pie, desnudas, con sus atributos sexuales aparentes, los pies separados 
y los brazos en el pecho, un ademán hierático que respeta una simetría axial. A los hombres se les representa con llauto, banda de tejido envuelta alrededor de la cabeza, que usaban los miembros masculinos de la etnia inca; sus lóbulos están perforados y estirados, lo que permitía colocar orejeras, adornos reservados a la élite. A menudo se les representa mascando coca, con una protuberancia visible en la mejilla. Las mujeres llevan pelo largo con raya al medio, a veces atado con un sujetador en la espalda. Las estatuillas han sido fabricadas por martillado o por fundición; algunos ejemplares macizos presentan incrustaciones de metal, resina de color o valva Spondylus (Bray, 1990). Ciertas estatuillas halladas en contexto aún conservaban su vestimenta en miniatura, adornos en fibras animales y vegetales, plumas, etc. (Dransart, 1995; 2000; Rowe, 1996).

Estas estatuillas votivas y otros ejemplares asociados al período del Tahuantinsuyo o al estilo inca, se fueron incorporando a las colecciones privadas y públicas en el transcurso de los siglos XIX y XX. El fondo que se conserva en el musée du quai Branly - Jacques Chirac (París) es interesante desde el punto de vista formal y contextual a pesar de no ser muy cuantioso. Este artículo busca completar el corpus de estudio a disposición de los investigadores, al presentar el contexto de recolección así como los resultados preliminares obtenidos luego de la observación formal y del estudio tecnológico y físico-químico de la colección. Los casos que aquí se analizan invitan a reconsiderar nuestro conocimiento de un arte «inca»o indígena que se ha renovado desde el siglo XVI, incursionando en el arte popular, o a veces, inclusive, con falsificaciones.

\section{LAS ESTATUILLAS «INCAS» DE LAS COLECCIONES NACIONALES FRANCESAS}

El musée du quai Branly - Jacques Chirac es el heredero de dos instituciones venerables en el sector patrimonial francés: el musée d'etnographie du Trocadéro (1878-1937) y el musée de l'Homme (desde 1937). Las colecciones arqueológicas de las que es garante desde 2004 llegaron a Francia hace aproximadamente dos siglos, época en que la recolección etnográfica no se realizaba de manera exhaustiva $y$, mucho menos, documentada. De este modo, las piezas carecen a menudo de contexto arqueológico. No obstante, los inventarios antiguos nos informan sobre la fecha de recolección o de ingreso a las colecciones, y a veces sobre la región de procedencia.

Las piezas de orfebrería atribuidas a los incas, o de influencia inca, destacan por el período remoto en que llegaron a Francia. El primer ingreso se registró en el musée du Louvre. En 1826 la institución adquiere 21 objetos americanos provenientes de la colección personal de Dominique-Vivant Denon ${ }^{1}$, puesta en venta luego de su fallecimiento (Riviale, 1996: 374). Entre las piezas se encuentra la estatuilla en miniatura de plata maciza ( $\mathrm{n}{ }^{\circ}$ inv. 71.1887 .135 .8 ) de un hombre

1 Catálogo del musée d'ethnographie du Trocadéro, n. ํ2 20039, D000552/28797. 


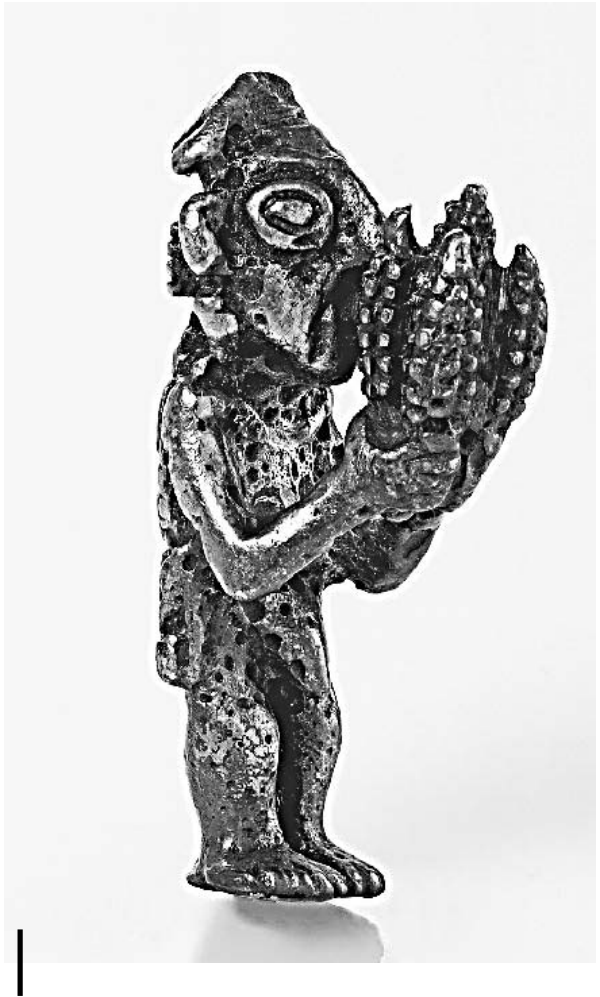

Figura 1 - Personaje masculino sosteniendo cinco mazorcas de maíz

Aleación de plata; 4,5 x 1,5 x 2,2 cm; $28 \mathrm{~g}$; musée du quai Branly - Jacques Chirac, n. ${ }^{\circ}$ inv. 71.1887.135.8

(C) Musée du quai Branly - Jacques Chirac Foto: Claude Germain que sostiene con sus manos cinco mazorcas de maíz (fig. 1). La pieza no se describe con precisión en el catálogo de venta redactado por J. J. Dubois, dibujante del departamento de las antigüedades egipcias del musée du Louvre. Se menciona: «Una estatuilla mexicana de plata», precisamente la única que puede corresponder a este objeto (Guimarães, 1994: 60). Es evidente que se perdió o que nunca se conoció la procedencia precisa de la estatuilla, de la que se sabe, sin embargo, que es americana.

Años mástarde, en 1854, el fondo del musée du Louvre se enriquece con la adquisición de la colección del diplomático Auguste Lemoyne2, cónsul general de Francia en Lima de 1840 a 1849 (Riviale, 1996: 374): unas 200 piezas, entre las cuales se encuentran una estatuilla femenina maciza de bronce (n. ${ }^{\circ}$ inv. 71.1887.114.87; dimensiones: $6,3 \times 1,9 \times 1,8 \mathrm{~cm}$; peso: $79,4 \mathrm{~g})$, con cabeza voluminosa, piernas unidas y volúmenes muy redondeados; una estatuilla de llama (hueca) de plata, a la cual le faltan tres pies y la cola (n. inv. 71.1887.114.92; dimensiones: $6 \mathrm{x}$ 4,6 x 1,3 cm; peso: 7,2 g) y, finalmente, una destacable estatuilla masculina (hueca) de plata con incrustaciones de pastas coloreadas ( $\mathrm{n}^{\circ}$ inv. 71.1887.114.90). Esta

última ha sido representada con ambas manos en el pecho, ataviada con orejeras y llauto (fig. 2). Destacable por su tamaño, sus grandes orejeras y su decoración colorida, la estatuilla ya había llamado la atención del francés Francis de Castelnau, quien realizó una expedición a América del Sur (1843-1847) y elaboró un bosquejo durante su visita a la colección Lemoyne en Lima (fig. 3; Castelnau, 1852: lám. 36): dibujada con cierta libertad, la estatuilla no presentaba las soldaduras groseras en la juntura de las piernas y los pies que hoy la caracterizan, sin que podamos tener la certeza de que estas reparaciones fueron realizadas después de esta fecha o que fueron voluntariamente omitidas por el dibujante. Única en su género, la estatuilla

2 Catálogo del musée d'ethnographie du Trocadéro, n. ${ }^{\circ} 21114-21117$ y 21119, D000552/28824, referencias de las estatuillas metálicas de la colección con forma de mujer, hombre o camélido. Dos estatuillas masculinas, una de plata y otra de cobre, han desaparecido del musée de l'Homme (n. ${ }^{\circ} 71.1887 .114 .88$ y n. $\left.{ }^{\circ} 71.1887 .114 .91\right)$. 


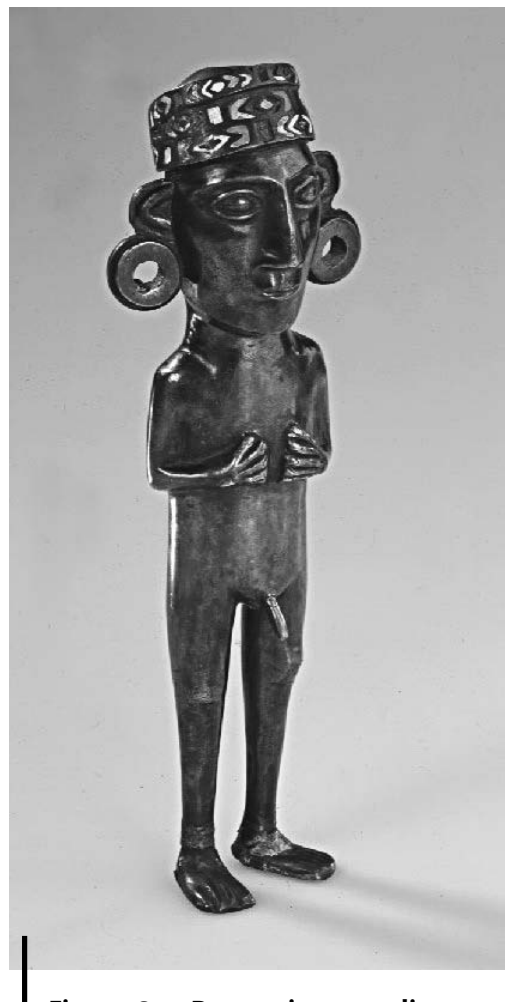

Figura 2 - Personaje masculino con Ilauto y orejeras

Plata; pastas coloreadas; $20,1 \times 6,4 \times$ $4,5 \mathrm{~cm} ; 210 \mathrm{~g}$; musée du quai Branly - Jacques Chirac, n. ${ }^{\circ}$ inv. 71.1887.114.90

(c) Musée du quai Branly - Jacques Chirac Fotos: Patrick Gries, Valérie Torre

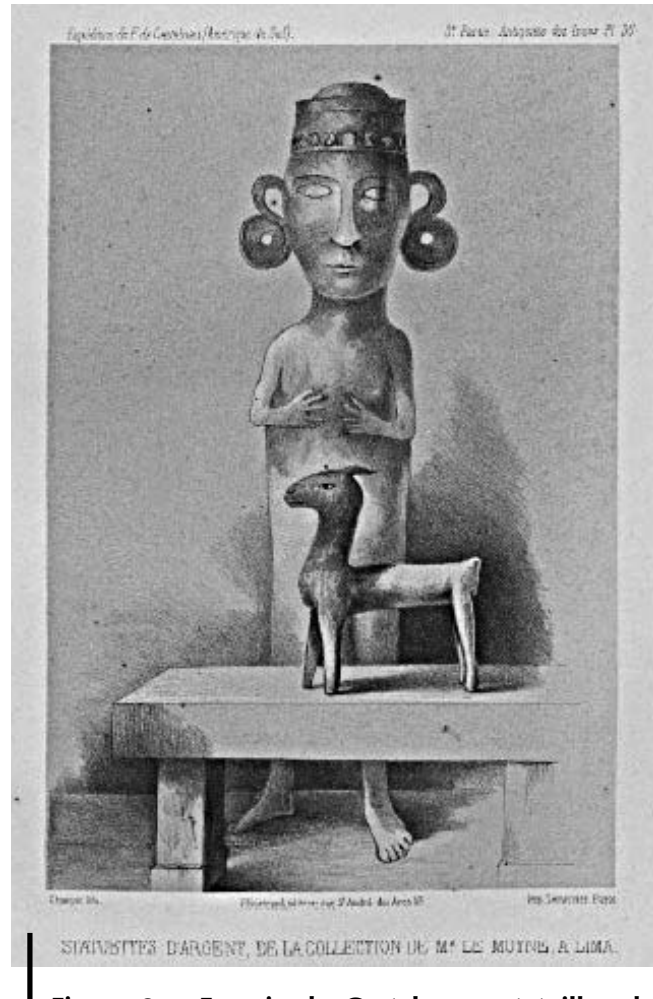

Figura 3 - Francis de Castelnau, estatuillas de plata de la colección de Don Auguste Le Moyne en Lima

Extraída de Castelnau, 1852: lámina 36

ha sido frecuentemente citada y reproducida (Jones, 1964: fig. 34; Lapiner, 1976: fig. 684; Levenson, ed., 1991: fig. 448) y, sin embargo, no ha sido estudiada. Se desconoce su procedencia, así como la del resto de la colección Lemoyne.

Una atípica estatuilla de noble inca ( . $^{\circ}$ inv. 71.1887.129.10; dimensiones: 7,5 x 1,8 x 1,6 cm; peso: 60,6 g) fue recolectada por Alfred Grandidier en Cuzco, durante su viaje de exploración por América del Sur realizado entre 1857-1858 y $1862^{3}$. Elaborada en bronce macizo, su rostro tiene proporciones alargadas y su factura relativamente grosera la distingue de la producción inca. Fue donada al musée du Louvre en 1876.

Al año siguiente, Vicente Fidel López, exrector de la Universidad de Buenos Aires (Riviale, 1996: 391), enriquece la colección con la donación de cuatro estatuillas 


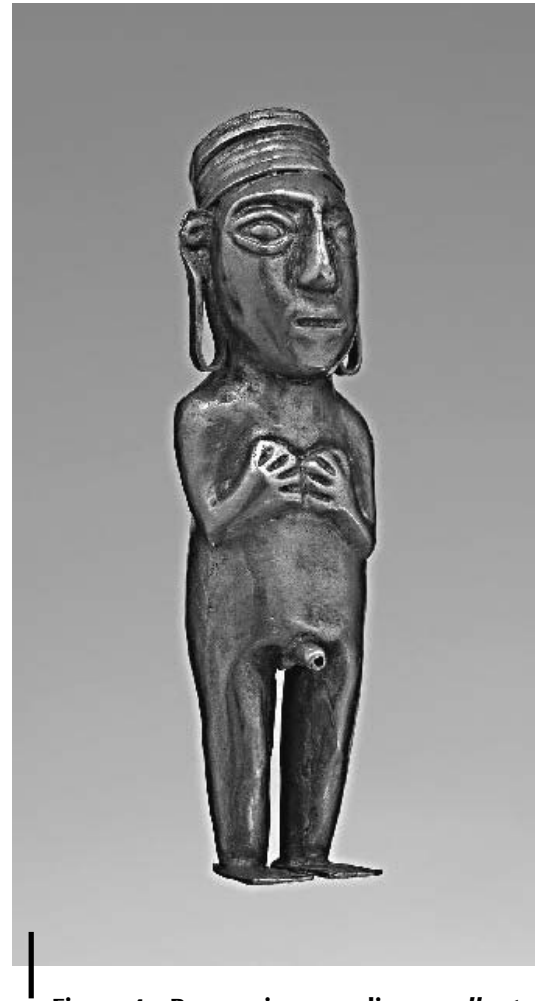

Figura 4 - Personaje masculino con Ilauto

Oro; 5,8 x 1,6 x 1,4 cm; 7 g; musée du quai Branly - Jacques Chirac, n. ${ }^{\circ}$ inv. 71.1887.130.2

(C) Musée du quai Branly - Jacques Chirac Fotos: Thierry Olivier, Michel Urtado

incas de factura muy fina, provenientes de Trujillo (Perú, costa norte), de las cuales solo permanecen tres 4 . Se trata de una estatuilla (hueca) de oro que representa a un noble inca (n. ${ }^{\circ}$ inv. 71.1887.130.2; fig. 4); una estatuilla de llama (hueca) de oro con orejas largas - hoy faltantes- $(\mathrm{n}$. inv. 71.1887.130.3; dimensiones: 5 x 5,8 $x$ 1,2 cm; peso: $8 \mathrm{~g}$ ); una estatuilla de llama (maciza) con aleación de plata y cobre $\left(\mathrm{n}\right.$. $^{\circ}$ inv. 71.1887.130.5; dimensiones: $5 \times 0,7$ x 3,9 cm; peso: $18,1 \mathrm{~g}$ ); todas con estilo inca característico.

En 1878, Charles Wiener, joven profesor de alemán que realizó una exitosa expedición de veintiún meses en los Andes centrales (1875-1877), dona una admirable colección de objetos arqueológicos al regresar a Francia. Se pueden enumerar dos estatuillas macizas identificadas como incas en diversas publicaciones (Jones, 1964: fig. 40; Lapiner, 1976: fig. 684). Se trata de un ciervo echado (n. ${ }^{\circ}$ inv. 71.1878.2.416) y de un personaje sentado junto a una mujer y a un hombre de menor tamaño que sostienen respectivamente un plato y un aríbalo de formas incas $\left(n .^{\circ}\right.$ inv. 71.1878.2.298.1-2; fig. 5)5. En el relato de su viaje, Wiener precisa que encontró este «curioso ídolo [...] en una cueva de Sacsayhuamán» (Wiener, 2010 [1880]: 370); el ciervo y otros diez «ídolos» provendrían del mismo contexto (Wiener, 2010 [1880]: 370, 588). Asimismo, Wiener trajo una estatuilla de camélido de bronce macizo, muy corroída y sin procedencia precisa (n. ${ }^{\circ}$ inv. 71.1878.2.633; dimensiones: $3,3 \times 0,5 \times 2,8 \mathrm{~cm})^{6}$.

En 1878 se funda el musée d'ethnographie du Trocadéro. Su función era reunir los archivos materiales de las producciones presentes y pasadas del mundo entero. La colección Wiener fue la segunda que se inventarió y, en 1887, se depositó

4 Catálogo del musée d'ethnographie du Trocadéro, del n. 21329 al 21332, D000552/28830. La estatuilla masculina de plata desapareció en el musée de l'Homme (n. ${ }^{\circ}$ 71.1887.130.4 D).

5 Ilustrada y descrita por Hamy, 1897: lámina LIII, fig. 150.

6 Catálogo del musée d'ethnographie du Trocadéro, n. ${ }^{\circ}$ 4056, D000558/28622, correspondiente a la figura de tres personajes. De las otras dos piezas solo se conserva el registro en el catálogo del musée de l'Homme. 


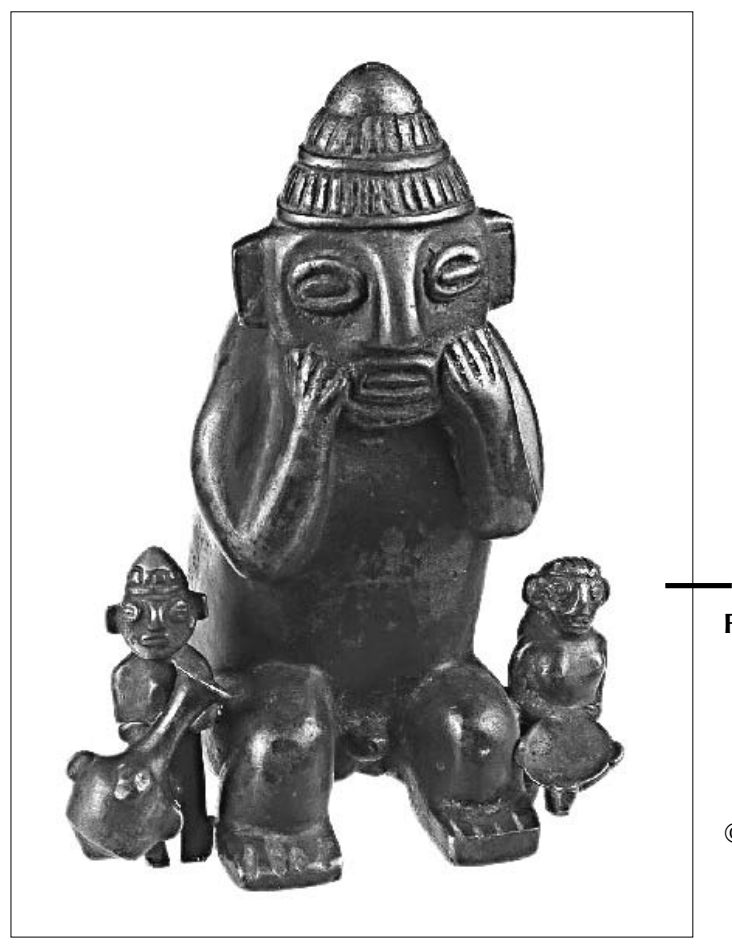

Figura 5 - Personaje masculino en cuclillas acompañado por un hombre con aríbalo y una mujer con un plato

Plata recubierta de plomo; $12,6 \times 9,1 \times$ $8,6 \mathrm{~cm} ; 2416$ g; musée du quai Branly -

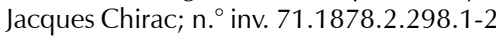

(c) Musée du quai Branly - Jacques Chirac

en el fondo amerindio del musée du Louvre. Habría que esperar el inicio del siglo XX para que lleguen a Francia nuevas piezas orfebres incas. Se trata de tres estatuillas —en una aleación con alto porcentaje de cobre-donadas por el capitán Paul Berthon en 1911 (n. ${ }^{\circ}$ inv. 71.1911.21.368, 71.1911.21.369, 71.1911.21.476) (Berthon, 1911). Sin embargo, su factura grosera y atípica permitió identificarlas rápidamente como falsas7 ${ }^{7}$.

Luego de haber sido constituido en el musée d'ethnographie du Trocadéro, ese fondo8 fue transferido al musée de l'Homme en 1937 y, en 2004, pasó a formar parte de las colecciones del musée du quai Branly - Jacques Chirac.

\section{TÉCNICAS ORFEBRES INCAS}

Las destrucciones y los saqueos posteriores a la conquista española dejaron escasos testimonios del arte orfebre inca. Los objetos de oro y plata que se han conservado hasta nuestros días no reflejan más que una ínfima parte de esta producción suntuaria que integraba adornos, vasos ceremoniales, estatuillas votivas, ornamentos

7 Registro de inventario de la colección Berthon, n. ${ }^{\circ} 11.21 .368$ y 11.21.369, D00370/44478, y 11.21.476, D00370/44482.

8 El corpus estudiado puede verse en la base de datos del musée du quai Branly - Jacques Chirac. 
arquitectónicos, etc. En el caso de las estatuillas en miniatura mencionadas en este artículo se trata, la mayoría de las veces, de piezas que fueron depositadas como ofrendas en lugares sagrados y santuarios y fueron utilizadas en el marco del ritual de la capacocha, que puede traducirse como «obligación real» o «gran don» (Itier, 2008: 128). Este gran acto de ofrenda estaba destinado esencialmente a implorar a las huacas o entidades naturales sagradas. Este ritual reactivaba los mecanismos de reciprocidad política, social y económica establecidos durante el Imperio inca en momentos críticos para el soberano: nacimiento de un heredero, su ascenso al trono, fallecimiento del soberano, anexión de una comunidad no inca al Tahuantinsuyo, etc. (Duviols, 1976; McEwan \& van de Guchte, 1992; Mignone, 2015). Solo algunas estatuillas fueron halladas en contexto (Mostny, ed., 1957; McEwan \& van de Guchte; 1992; Heyerdahl et al., 1995; Schobinger, ed., 2001; Reinhard \& Ceruti, 2010; Mignone, 2015).

El primer estudio completo de los objetos que acompañaban un ritual de capacocha se realizó en 1957 y fue el de la momia del Cerro El Plomo en Chile (trabajos recopilados por Mostny, ed., 1957). Oberhauser \& Fuhrmann (19571959) dirigieron el estudio físico-químico de los objetos metálicos, no solo el de la estatuilla femenina de plata y el del camélido de oro, realizados por martillado, sino también el de los otros tres objetos de plata del ajuar del niño sacrificado en este santuario de altura.

Hubo que esperar los años 1990 y 2000 para que se renovara el interés por ese material. En 1995, Penny Dransart propuso un primer estudio de las estatuillas votivas incas con un enfoque que combinaba fuentes arqueológicas, etnohistóricas e iconográficas, intentando dar cuenta de su valor simbólico y ritual (Dransart, 1995). Al basarse en un corpus heterogéneo de piezas —entre las cuales algunas conservaban su vestimenta de origen, en miniatura-, Dransart privilegió el análisis del contexto de utilización y la interpretación del simbolismo de los materiales en pos de explorar las representaciones visuales de los elementos naturales y su relación con los paisajes sagrados de los Andes. En un estudio posterior (2000), Dransart analiza las asociaciones de materiales con respecto a las estatuillas e indaga sobre la pertinencia de la distinción metodológica entre forma y significación para la comprensión del arte visual inca.

Acerca de los estudios tecnológicos se pueden citar los trabajos de Immina von Schuler-Schömig (1981) y de Salvador Rovira Lloréns (1990) que realizaron el análisis tecnológico de una selección de piezas prehispánicas del Ethnologisches Museum de Berlín y el estudio sistemático de aleaciones empleadas en las producciones prehispánicas y coloniales sudamericanas del Museo de América en Madrid, respectivamente. El estudio de las composiciones de los objetos incas de la colección madrileña se complementó con un artículo de Rovira Lloréns \& Gómez Ramos (1995). La descripción tecnológica de las estatuillas conservadas en la Dumbarton Oaks Research Library and Collection se publicó un año después (Rowe, 1996).

En 2004, Roberto Bárcena realizó el segundo estudio tecnológico y físico-químico completo de estatuillas provenientes de un contexto de capacocha. Este analiza tres estatuillas halladas en el sitio ceremonial del Cerro Aconcagua (Mendoza, Argentina) (Bárcena, 2004). 
La falta de investigaciones sobre los objetos de ofrenda incas — en especial de estatuillas antropomorfas y zoomorfas- nos condujo a examinar la colección del musée du quai Branly - Jacques Chirac. El corpus estudiado en el marco de este artículo se compone de catorce piezas ${ }^{9}$. El estudio tecnológico y físico-químico de las estatuillas se pudo realizar en el laboratorio de análisis del museo, lo cual aportó nuevos datos que permitieron completar nuestros conocimientos al respecto ${ }^{10}$. Estas fueron analizadas bajo lupa binocular para detectar sus técnicas de montaje y decoración; en el caso de las más complejas, una radiografía de rayos $\mathrm{X}$ permitió una mejor percepción de las zonas de ensamblado. El análisis de las aleaciones empleadas en su fabricación fue efectuada de manera no destructiva, mediante las técnicas de espectrometría de fluorescencia de rayos $X$ (FRX) con un equipo Thermo Scientific Niton XL3t y de microscopía electrónica de barrido acoplada a la espectrometría por dispersión de energía de rayos $X$ (MEB-EDS) con un Hitachi TM300011.

\section{ARTE IMPERIAL INCA Y ORFEBRERÍA RITUAL}

La producción orfebre inca parece muy estandarizada, sobre todo en el caso de las estatuillas en miniatura. Esta uniformización de la producción artística inca, que se observa en la orfebrería, los textiles y la cerámica, tenía el objetivo de establecer una cultura visual común que pudiera fortalecer y exponer la presencia inca dentro del imperio (Cummins, 2015: 172), aunque existió una producción local paralela que siguió siendo activa. El corpus de estatuillas incas incluye a hombres, mujeres y camélidos en miniatura elaborados con aleaciones de tenor variable de oro, plata y cobre, a las que se añaden especímenes producidos en valvas de Spondylus.

La forma de las estatuillas se obtuvo por martillado o por fundición. En el primer caso, las estatuillas se ensamblaron mediante la soldadura de láminas metálicas. Las miniaturas pertenecientes al musée du quai Branly - Jacques Chirac miden entre 5 y 20,1 cm. Las estatuillas de la colección Vidal-Senèze, que presentaremos a continuación, son una muy buena muestra de piezas refinadas y características del estilo inca.

La estatuilla antropomorfa (.$^{\circ}$ inv. 71.1887.130.2; fig. 4) representa a un noble inca con llauto, con las manos sobre el pecho. La observación con lupa binocular confirmó que fue realizada, como numerosas estatuillas de este tipo

9 Hemos dejado de lado las piezas del museo que se encuentran en el depósito, cuya situación jurídica no está claramente definida.

10 Numerosas piezas prehispánicas de la colección del musée de l'Homme fueron analizadas y estudiadas por Henri Arsandaux, profesor en la Escuela de Física y Química de París, y Paul Rivet, director del museo, en el marco de investigaciones pioneras sobre la orfebrería prehispánica (Rivet \& Arsandaux, 1946). No obstante, las estatuillas consideradas en este artículo no fueron objeto de análisis cuantitativos de materiales.

11 Véase la discusión sobre la aplicación de estas técnicas al estudio de metales preciosos en Guerra (2008a) y en Troalen \& Guerra (2016). 

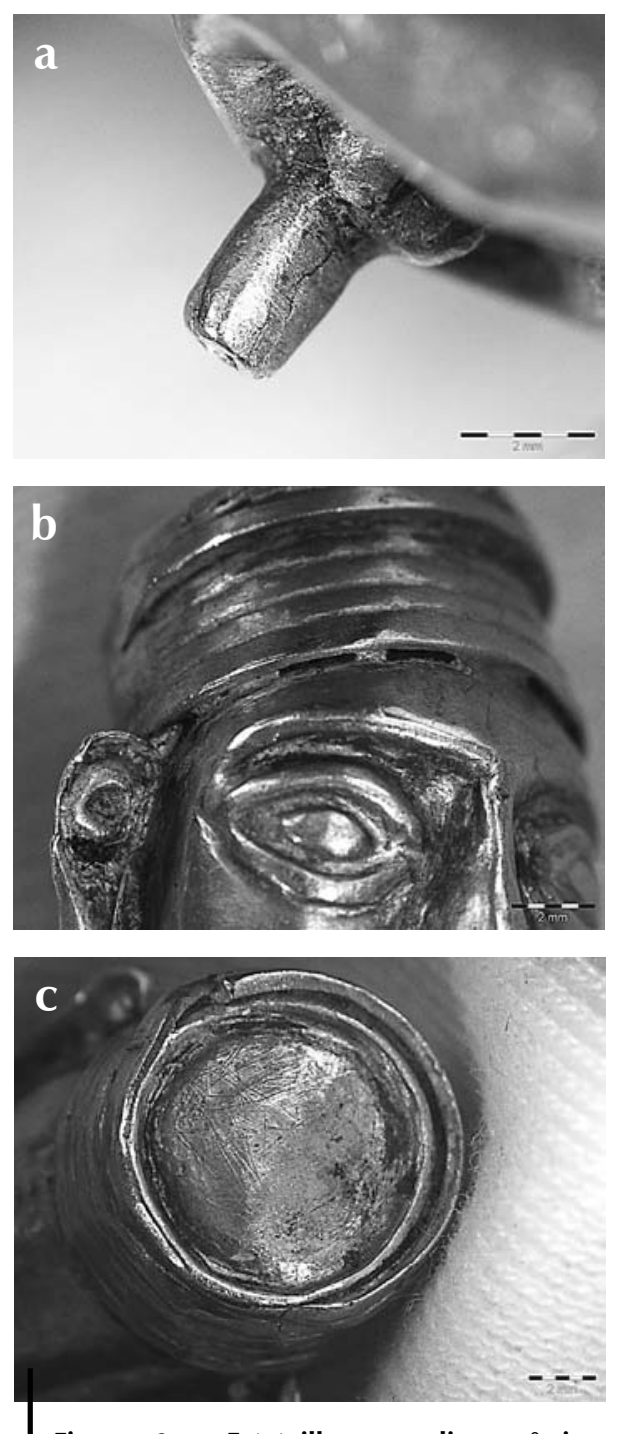

Figura 6 - Estatuilla masculina $n .^{\circ}$ inv. 71.1887.130.2: detalles de las soldaduras de las láminas que representan el sexo (a) y la banda del personaje (b y c)

Imágenes obtenidas bajo lupa binocular Realización: M. F. Guerra
(Rowe, 1996: 302-309, fig. 107 y 108), a partir de láminas recortadas, repujadas y soldadas. Se representan el rostro, el torso y las piernas con una lámina repujada y enrollada hacia el interior y soldada a nivel de la espalda. La parte inferior de esta lámina fue recortada en dos y enrollada para formar las extremidades cilíndricas que representan las piernas. Luego, la lámina fue soldada en la cara interna. Para confeccionar los brazos y las manos, la lámina fue repujada y el detalle de los dedos fue mejorado por cincelado. Los pies fueron elaborados con láminas soldadas a las piernas; cuatro líneas groseramente cinceladas esbozan los dedos del pie. Se añadieron otras dos láminas para cubrir la cabeza y confeccionar el llauto o banda que la ciñe: una lámina, con forma de cinta, presenta líneas cinceladas en el contorno para crear la ilusión de que la banda está enrollada alrededor de la cabeza; la otra, circular, representa la parte superior de la cabeza (figs. 6c y $7 \mathrm{~b}$ ). Finalmente, ambas orejas fueron elaboradas a partir de un alambre de sección cuadrada que fue martillado en la parte superior para representar el lóbulo en repujado y, luego, soldado a la cabeza (fig. 7a). El sexo ha sido realizado de forma independiente a partir de una lámina enrollada y soldada. A su vez, esta fue nuevamente soldada a la estatuilla (fig. 6a).

Desde el punto de vista estilístico, esta estatuilla responde a las formas más clásicas dentro de la producción inca. La proporción de la cabeza con respecto al cuerpo es de un tercio aproximadamente. La figura ha sido representada con una perfecta simetría axial. El rostro es ovalado y una recta representa la boca; la nariz derecha, triangular, se une con las cejas horizontales a la altura de la frente; los ojos con forma de almendra están rodeados de una línea en relieve que representa unos párpados gruesos. La expresión del rostro es imperturbable y en la mejilla izquierda se ve el bolo de coca. 

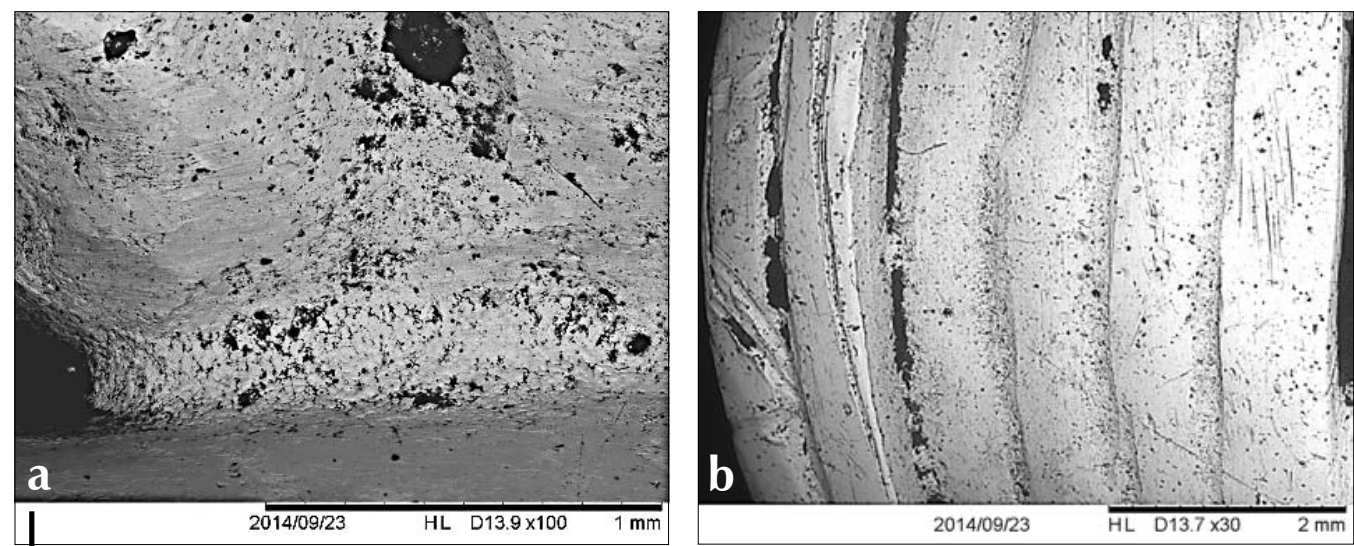

Figura 7 - Imágenes tomadas por MEB originadas por electrones secundarios de las soldaduras de la estatuilla $n .^{\circ}$ inv. 71.1887 .130 .2 : la que une la oreja al rostro (a) y las que unen los elementos del llauto (b)

(C) Musée du quai Branly - Jacques Chirac

Realización: C. Moulherat

El análisis por FRX y MEB-EDS (cuadro 1) de diferentes elementos de la estatuilla revela no solamente la composición de las aleaciones empleadas en la fabricación de las láminas de oro, cuyo tenor en plata es muy elevado, sino también la utilización en el ensamblado de una soldadura cuya composición es más rica en cobre a fin de reducir el punto de fusión. La figura 7 muestra la imagen tomada con el MEB de la soldadura que une la oreja al rostro del personaje.

\section{Cuadro 1 - Resultado del análisis por FRX y MEB-EDS de diferentes elementos de la estatuilla $n .^{\circ}$ inv. 71.1887 .130 .2}

\begin{tabular}{|l|ccc|}
\hline & Au \% & Ag \% & Cu \% \\
\hline Cuerpo & 63,4 & 35,1 & 1,5 \\
Llauto & 61,1 & 37,5 & 1,7 \\
Pie & 62,5 & 35,8 & 1,8 \\
Soldadura oreja & 69,6 & 23,8 & 6,7 \\
\hline
\end{tabular}

La estatuilla de llama de la colección (n. ${ }^{\circ}$ inv. 71.1887.130.3), fue realizada de la misma manera que la estatuilla masculina de oro. La cabeza, las orejas, el cuello, las patas, el cuerpo, la cola, el sexo y las pezuñas fueron obtenidos enrollando láminas que luego fueron soldadas entre sí (fig. 8). El detalle anatómico está enfocado en la cabeza del animal y en particular en su hocico, que es la parte mejor trabajada desde este punto de vista. 

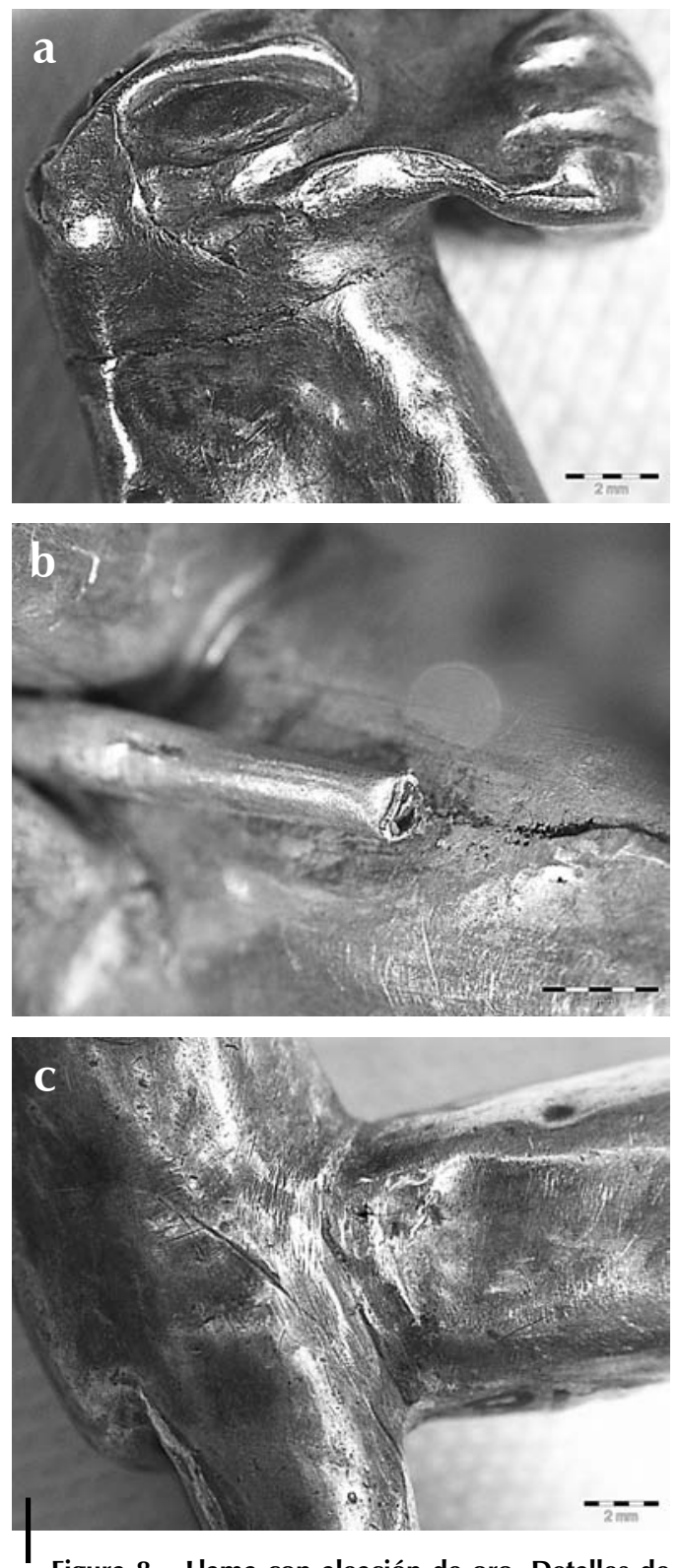

Figura 8 - Llama con aleación de oro. Detalles de las soldaduras del cuello y la cabeza (a), del sexo y el vientre (b) y de las patas (c)

Altura: 5,0 cm; peso: $8 \mathrm{~g}$; musée du quai Branly Jacques Chirac, n. ${ }^{\circ}$ inv. 71.1887.130.3

Imágenes obtenidas bajo lupa binocular Realización: M. F. Guerra 
El análisis por FRX (cuadro 2) de diferentes elementos de la estatuilla revela la utilización de aleaciones que también contienen una alta concentración de plata. La composición de las láminas utilizadas para elaborar los pies de la estatuilla presenta un porcentaje más elevado de cobre; esto evidencia que se trata de una aleación diferente.

\section{Cuadro 2 - Resultado del análisis por FRX y MEB-EDS de diferentes elementos de la estatuilla . $^{\circ}$ inv. 71.1887 .130 .3}

\begin{tabular}{|l|ccc|}
\hline & Au \% & Ag \% & Cu \% \\
\hline Cuerpo & 69,9 & 28,4 & 1,6 \\
Cabeza & 71,1 & 27,9 & 1,1 \\
Cola & 67,9 & 30,9 & 1,2 \\
Pata & 67,9 & 30,7 & 1,4 \\
Pezuña & 63,5 & 33,3 & 3,4 \\
\hline
\end{tabular}

Entre los objetos de la colección Lemoyne se encuentra también una estatuilla de llama de plata (n. ${ }^{\circ}$ inv. 71.1887 .114 .92$)$ que responde a las mismas características estilísticas y tecnológicas que la estatuilla anterior (n. ${ }^{\circ}$ inv. 71.1887.130.3), pero cuyos detalles del repujado del hocico, de los ojos y de las orejas son de mejor calidad, como se puede observar en la figura 9. El análisis por FRX de la estatuilla revela la utilización de aleaciones plata-cobre de muy buena calidad, con un tenor en plata que varía entre 98 y $99 \%$. También se han observado aleaciones de plata de muy buena calidad en el caso de otras estatuillas (véase discusión en Vetter Parodi \& Guerra, en este volumen) y, en particular, en las estatuillas provenientes de la Isla de Coati (Lago Titicaca, Bolivia), que pertenecen a la colección del Ethnologisches Museum de Berlín (Guerra et al., en este volumen), de San Jerónimo en Cuzco, que pertenecen a la colección Larrea del Museo de América de Madrid (Rovira Lloréns \& Gómez Ramos, 1995) y de Paucartambo, que pertenecen a la colección del Museo Inka del Cuzco (Sierra Palomino \& Guerra, en este volumen).

Otras dos estatuillas de llamas del musée du quai Branly - Jacques Chirac, realizadas por fundición, cumplen con los cánones incas: la de la colección Fidel López (n. ${ }^{\circ}$ inv. 71.1887.130.5) y la de la colección Wiener (n. ${ }^{\circ}$ inv. 71.1878.2.633). Con respecto a las aleaciones, la primera es cercana a las anteriores con la siguiente composición: 93,6\% Ag; 5,4\% Cu; 0,4\% Pb y 0,6\% Sn. La segunda, en cambio, fue elaborada en bronce (contiene $84,5 \% \mathrm{Cu} ; 15 \%$ Sn y $0,5 \% \mathrm{~Pb}$ ). 

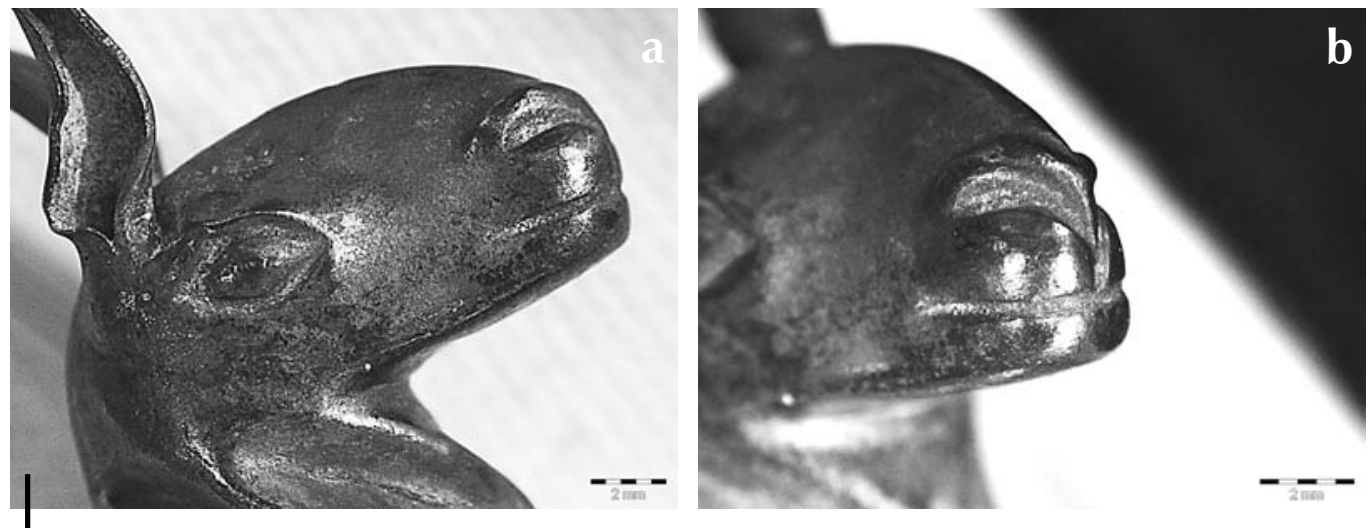

Figura 9 - Llama, aleación de plata y cobre. Detalles de los ojos y las orejas (a) y del hocico (b) Altura: 6,0 cm; peso: 7,2 g; musée du quai Branly - Jacques Chirac, n. ${ }^{\circ}$ inv. 71.1887.114.92 Imágenes obtenidas bajo lupa binocular Realización: M. F. Guerra

\section{LA HERENCIA DE UNA TRADICIÓN ORFEBRE: VARIEDADES Y VARIACIONES EN EL ESPACIO Y EN EL TIEMPO}

\section{1. La estatuilla masculina de la colección Lemoyne}

La estatuilla n. ${ }^{\circ}$ inv. 71.1887.114.90 (fig. 2) es el único ejemplar conocido que luce las orejeras de la nobleza inca12. También es una pieza atípica por otros motivos,

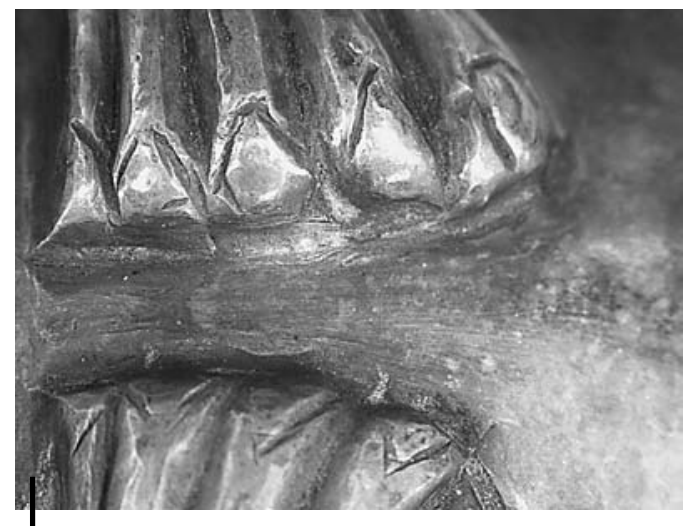

Figura 10 - Estatuilla masculina $n .^{\circ}$ inv. 71.1887.114.90. Detalle del cincelado de las uñas Imágenes obtenidas bajo lupa binocular Realización: M. F. Guerra por ejemplo su gran tamaño $(20,1 \mathrm{~cm})$ y peso (210 g) en una pieza hueca, así como las incrustaciones coloreadas de materias desconocidas que decoran el llauto.

La estatuilla respeta la postura hierática y la simetría axial características de las estatuillas incas: tiene proporciones más alargadas (con respecto al cuerpo, la proporción de la cabeza es casi de un cuarto); el cuello largo y rasgos más angulosos, principalmente en el rostro (mentón, pómulos, puente nasal), los hombros y las rodillas. Otro detalle poco común en este tipo de producción es el cincelado de las uñas de las manos (fig. 10). Es de factura muy cuidada, como se observa a menudo en las estatuillas de mayor tamaño (Rowe, 1996: 302).

12 Burger y Salazar mencionan la presencia de numerosas estatuillas masculinas con orejeras pero no precisan los ejemplos considerados (Burger \& Salazar, 2004: 198). 
Recientemente se cuestionó la autenticidad de esta pieza, fundamentalmente por su pátina negra tan oscura — que difiere de la pátina resultante de la alteración natural de la plata - más parecida a una pátina artificial. Esta técnica tuvo su auge en el siglo XIX para dar al objeto una lectura «antigua» (Hughes, 1993), o incluso de «buen gusto» según los cánones de la época (Rudoe, 1993).

La radiografía de la pieza (fig. 11) confirmó, sin embargo, una fabricación conforme a la práctica inca, cuyo ensamblado es idéntico al de la estatuilla masculina (n. ${ }^{\circ}$ inv. 71.1887.130.2) de oro. Únicamente las orejas son distintas: en el caso de la estatuilla de oro, descrita anteriormente, las orejas se fabricaron de forma independiente (alambre de sección cuadrada soldado a la cabeza) con el lóbulo trabajado en repujado. En esta última, en cambio, las orejas fueron realizadas a partir de una chapa recortada para soportar ornamentos circulares, también de fabricación independiente (fig. 12).

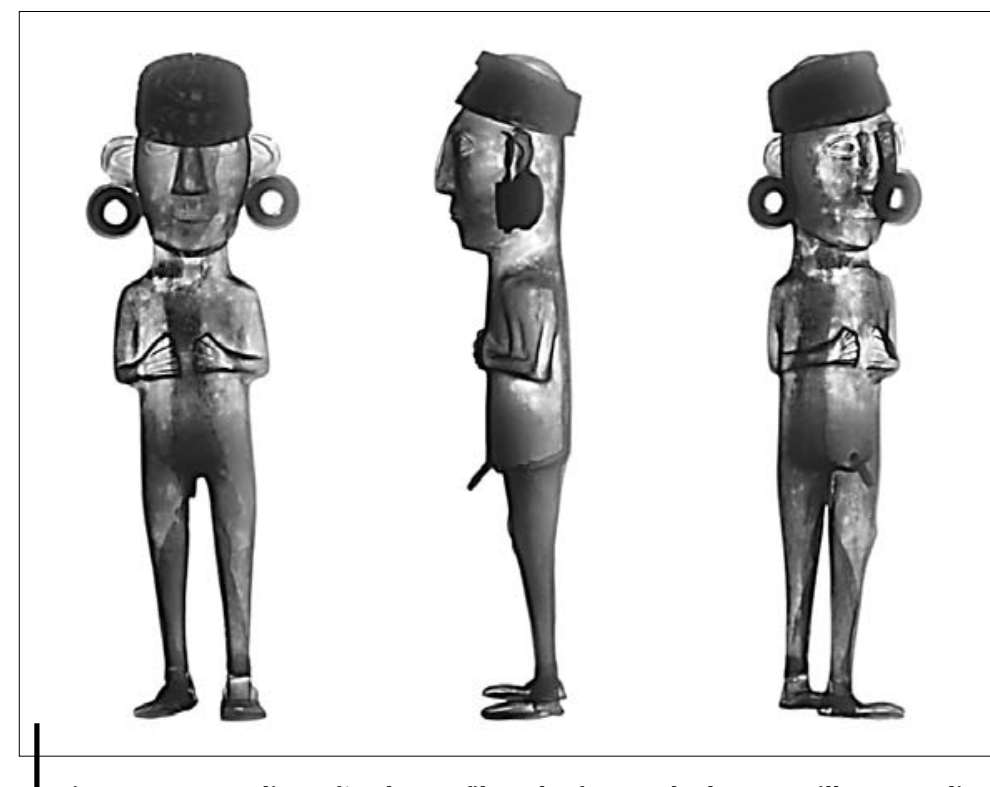

Figura 11 - Radiografía de perfil y de frente de la estatuilla masculina n. ${ }^{\circ}$ inv. 71.1887.114.90

(C) Musée du quai Branly - Jacques Chirac; Société Re.S.Artes

Las soldaduras que se ven en la unión de las piernas y los pies son gruesas. El análisis se ha realizado por FRX y los resultados indican una aleación típicamente moderna con altos porcentajes de estaño y plomo como lo muestra el cuadro 3 (en las soldaduras más finas se trata solamente de una estimación de la composición13).

13 En las soldaduras más finas, como el haz de rayos $\mathrm{X}$ es ancho, se trata de composiciones que corresponden a una mezcla de la composición de la soldadura y de las partes soldadas. 

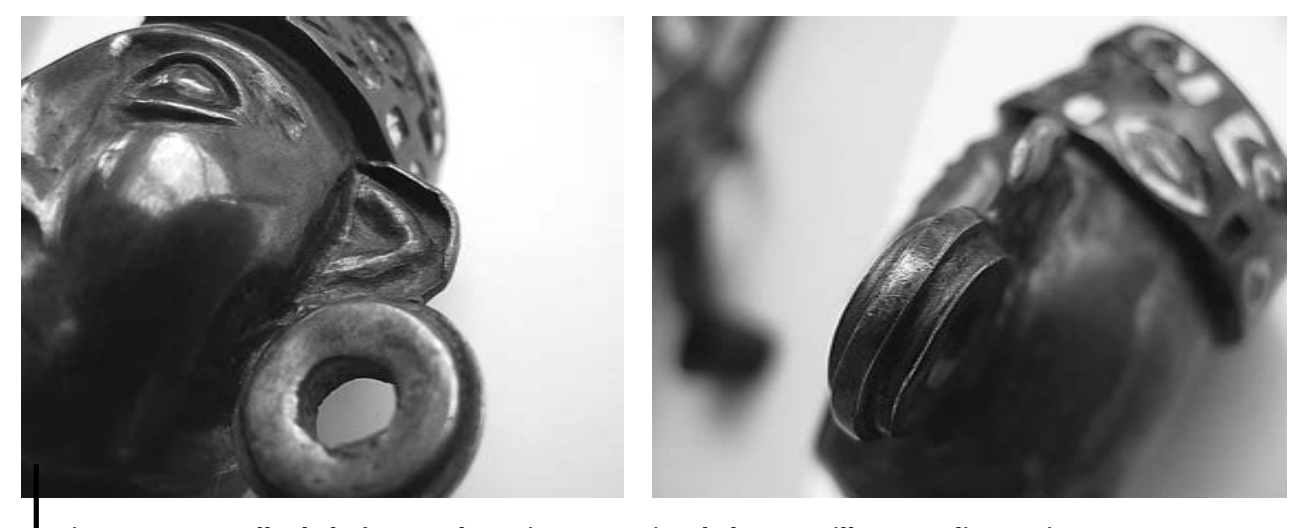

Figura 12 - Detalle de la factura de orejeras y orejas de la estatuilla masculina $n .^{\circ}$ inv. 71.1887 .114 .90 Imágenes obtenidas bajo lupa binocular Realización: M. F. Guerra

Cuadro 3 - Resultado del análisis por FRX de diferentes elementos y de las áreas de soldadura de la estatuilla $n .^{\circ}$ inv. 71.1887 .114 .90

\begin{tabular}{|l|cccc|}
\hline & Ag \% & Cu \% & Pb \% & Sn \% \\
\hline Cuerpo & 98,9 & 1,1 & & \\
Cabeza & 98,5 & 1,4 & & \\
Oreja & 99,1 & 0,9 & & \\
Soldadura espalda & & & 70,7 & 29,4 \\
Soldadura pie & 18,7 & 1,9 & 36,6 & 42,8 \\
\hline
\end{tabular}

En este mismo cuadro también presentamos el análisis por FRX de algunas partes de la estatuilla, lo que muestra que se trata —al menos en la superficie- de una aleación plata-cobre muy rica en plata. Las dimensiones de la estatuilla y del equipo disponible no permiten el análisis por MEB-EDS de la pátina. Al no tener a disposición in situ una técnica de análisis estructural para identificar los compuestos químicos que constituyen la pátina, no hemos podido realizar otras investigaciones analíticas. Los materiales utilizados en la fabricación de las incrustaciones tampoco fueron analizados.

En resumen, la pieza parece ser coherente con otras producciones incas; a su vez presenta variantes iconográficas, estilísticas y soldaduras típicamente coloniales o posteriores a este período. 


\section{2. La estatuilla masculina con mazorcas de maíz}

La estatuilla masculina (n. ${ }^{\circ}$ inv. 71.1887 .135 .8 ; fig. 1 ) corresponde a un tipo de producción bien afianzado del Horizonte Tardío (1450-1532 d. C.) que se distingue claramente — desde el punto de vista estilístico- de las estatuillas presentadas anteriormente. Muestra a un personaje masculino que sostiene cinco mazorcas de maíz con un ademán de presentación o de ofrenda. Junius Bird relaciona a este personaje con un bailarín o un participante ceremonial (Bird, 1979: 51). El hombre está de pie con las piernas levemente flexionadas, la mirada hacia adelante, el rostro neutro. Pareciera que lleva taparrabos, en la cabeza se ve un tocado trilobulado y su espalda está recubierta con motivos vegetales en los que se distinguen mazorcas de maíz a la altura de la nuca. La estatuilla tiene un orificio en la parte superior de la cabeza donde se sitúa la extremidad del tocado (fig. 13a) que parece haber sido realizado en el molde de fundición como el resto de los detalles de la decoración. En el área contigua al orificio se pueden observar huellas de abrasión que podrían deberse a la fricción. Asimismo, en otras partes de la estatuilla, por ejemplo en las mazorcas de maíz, pareciera haber cierta abrasión por fricción (fig. 13b). La estatuilla fue elaborada por fundición. No se perciben líneas de juntura de moldes múltiples, como es el caso de un ejemplar del American Museum of Natural History de Nueva York, realizado a partir de un molde dividido en diecinueve partes distintas (Lechtman, 1988: 352-353, figs. 30.16-30.18). La estatuilla tiene algunos defectos de fundición. En casi la totalidad de la superficie se observan cráteres, sobre todo en el pecho, detrás de los brazos, entre las piernas (fig. 14) y hasta en el interior del orificio de la cabeza, es decir, en las zonas donde es más difícil realizar el acabado.

Esta estatuilla corresponde a un tipo iconográfico del que se conservan ejemplares en colecciones privadas y públicas, cuyo contexto de recolección
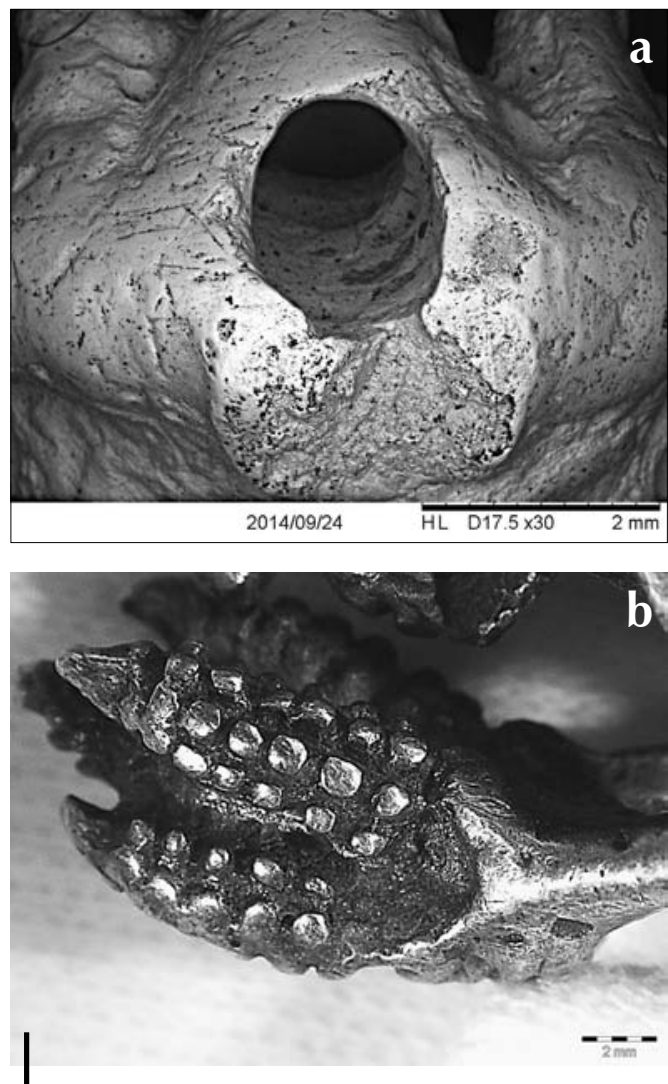

Figura 13 - Estatuilla masculina n..$^{\circ}$ inv. 71.1887.135.8: detalle del orificio en la parte superior de la cabeza (a) y de la abrasión en las mazorcas de maíz (b)

Imágenes obtenidas bajo lupa binocular Realización: M. F. Guerra 


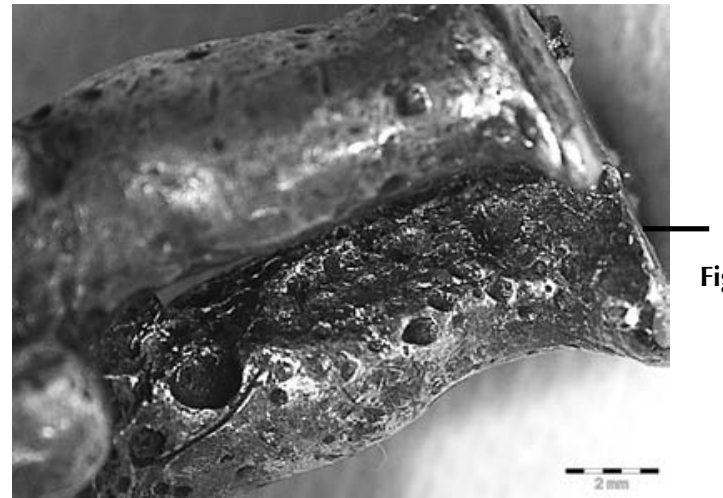

Figura 14 - Estatuilla masculina $n .^{\circ}$ inv. 71.1887.135.8: detalle de los cráteres entre las piernas

Imagen obtenida bajo lupa binocular Realización: M. F. Guerra

no está claramente definido ${ }^{14}$. Todas estas piezas presentan al mismo personaje con tocado trilobulado, espalda recubierta con motivos florales y mazorcas de maíz en las manos. La presencia de este grupo homogéneo ya había sido subrayada por Julie Jones (Jones, 1964: fig. 58-59) y Alan Lapiner (Lapiner, 1976: fig. 689-691)15. A ese conjunto de estatuillas se le añade otro que posee las mismas características materiales, estilísticas y de forma, pero que presenta personajes de ambos sexos con una gran variedad de actitudes: un señor con túnica y tocado de plumas que tiene en la mano una maza con porra en estrella típicamente inca16; una estatuilla femenina llevando a un bebé en brazos y un bolso en la espalda17; una estatuilla masculina que lleva un alto bonete cilíndrico y sostiene un vaso con rostro humano en relieve18; una estatuilla femenina que lleva un aríbalo inca19. El tamaño y las proporciones de las estatuillas son similares, tienen el mismo tipo de rostro con nariz prominente, ojos con forma de almendra y los surcos nasogenianos marcados; todas ellas fueron confeccionadas en plata, por fundición, y luego pulidas. La superficie de algunas presenta cráteres, pero en menor proporción y de menor tamaño que los del ejemplar del musée du quai Branly - Jacques Chirac.

Solo se conoce el lugar de recolección de la estatuilla B/9588 del American Museum of Natural History de Nueva York, que fue hallada en Ica, en la costa sur del

14 Estatuilla de la colección Nasli y Alice Heeramaneck, Nueva York, 7,6 cm de altura (Jones, 1964: fig. 59; Emmerich, 1965: fig. 57); estatuilla de la colección F. S. Hermann, 7 cm de altura (Lapiner, 1976: fig. 689); estatuilla del Ethnologisches Museum de Berlín, n.ํ inv. V A 28926 (Baessler, 1904: fig. 545); estatuilla del American Museum of Natural History, Nueva York, n. ${ }^{\circ}$ inv. T-86/1, 8,2 cm de altura.

15 Lapiner también menciona la representación de ese personaje en otros soportes, tal como un ejemplar de hueso conservado en la Universidad de Cambridge (Lapiner, 1976: fig. 690).

16 Estatuilla recolectada en Ica, costa sur del Perú, conservada en el American Museum of Natural History (Nueva York), B/9588, 6,5 cm de altura (Rowe, 1984: fig. 192; King, 2000: fig. 17).

17 Estatuilla de procedencia desconocida conservada en el Museo Nacional de Arqueología, Antropología e Historia del Perú (Lima), M-4450, 6,5 cm de altura (Núñez-Regueiro, ed., 2015: 56).

18 Estatuilla de procedencia desconocida conservada en el Museo Nacional de Arqueología, Antropología e Historia del Perú (Lima), M-4452.

${ }^{19}$ Estatuilla conservada en el Ethnologisches Museum de Berlín, V A 62445, 5,4 cm de altura. 
Perú (King, 2000: 46). La atribución cultural es imprecisa por falta de información acerca de su contexto de descubrimiento. Parecen reflejar el tipo de producción de la costa norte peruana: sus rostros concuerdan con otras producciones figurativas de madera y cerámica de la cultura Chimú 20 y con una serie de vasos de plata con rostro humano en relieve, de nariz puntiaguda prominente, hallados a lo largo de la costa peruana en sitios del Horizonte Tardío. Esta producción ha sido calificada como inca o inca provincial (Jones, 1964; Emmerich, 1965; Lapiner, 1976; Burger \& Salazar, 2004: 197). La estatuilla femenina del Museo Nacional de Arqueología, Antropología e Historia del Perú (MNAAHP) (M-4450) podría sugerir, asimismo, una atribución al período de dominación o de influencia inca21. El vestido del personaje sugiere una influencia de las tierras altas ya que lo lleva puesto con un lazo, el cual aparentemente no era el uso habitual de los vestidos en las zonas costeras. Por otro lado, el vestido está sujetado en cada hombro siguiendo la usanza inca. Finalmente, la bolsa de coca en bandolera con una correa ancha no es habitual en la costa central o meridional y alude más bien a una producción de las tierras altas22.

La estatuilla del musée du quai Branly - Jacques Chirac ha sido elaborada a partir de una aleación que contiene un alto porcentaje de plata (cuadro 4), como las estatuillas incas de la región de Cuzco elaboradas por fundición y martillado mencionadas en Vetter Parodi \& Guerra, en este volumen. Las dos estatuillas del mismo tipo conservadas en el MNAAHP también fueron analizadas por FRX con un equipo Thermo Scientific Niton modelo XL3T 950 GOLDD de Symtek en Perú. Su composición es próxima a la de la estatuilla del musée du quai Branly Jacques Chirac, mientras que la estatuilla del Ethnologisches Museum de Berlín es claramente diferente (para los detalles analíticos, véase Guerra et al., en este volumen), lo que podría indicar una factura más reciente (véase planteo en Vetter \& Guerra, en este volumen).

Cuadro 4 - Resultado del análisis por FRX de las estatuillas de tipo similar a la . $^{\circ}$ inv. 71.1887.135.8 del musée du quai Branly - Jacques Chirac (MQB), pertenecientes al Ethnologisches Museum de Berlín (EMB) y al Museo Nacional de Arqueología, Antropología e Historia del Perú (MNAAHP)

\begin{tabular}{|l|ccccc|}
\hline \multicolumn{1}{|c|}{ n. ${ }^{\circ}$ inv. } & Ag $\%$ & Cu $\%$ & Pb \% & Au \% & Sn \% \\
\hline MQB 71.1887.135.8 & 95,7 & 3,7 & 0,1 & & 0,5 \\
EMB 28926 & 71,9 & 27,9 & & 0,2 & \\
MNAAHP 4452 & 97,9 & 1,4 & & & 0,7 \\
MNAAHP 4450 & 97,0 & 2,3 & & & 0,7 \\
\hline
\end{tabular}

20 Véanse ejemplos de cerámica figurativa inca en Castro \& Kurella, eds. (2013: figs. 33, 40, 134).

21 Argumentando la ausencia de simetría bilateral tan característica de las estatuillas incas, así como la representación de personajes sistemáticamente vestidos, Heidi King propuso una datación colonial para este tipo de producción (King, 2000: 46).

22 Ann Rowe, The Textile Museum, Washington, D. C., comunicación personal, 6 de agosto de 2015. 
No cabe duda de que estas piezas corresponden a una producción estandarizada —al menos algunas de ellas - y que tal vez pertenezcan al Horizonte Tardío o al período posterior a la conquista europea, o a ambos.

\section{INDIGENISMO Y ARTE POPULAR}

Por otro lado, hay una serie de estatuillas, de bronce en su mayoría y realizadas por fundición, que corresponden sin lugar a dudas a producciones modernas, realizadas en Perú y conservadas actualmente en diferentes colecciones públicas. Se trata de piezas bastante groseras — identificadas como falsas tempranamentecomo las piezas de la colección Berthon mencionadas anteriormente. Estas presentan a menudo, en el caso de personajes masculinos, un tocado parecido a un bonete, pero que corresponde probablemente a un llauto inca, representado aquí de manera deformada. El ejemplar de la colección Berthon Ileva además orejeras (n. ${ }^{\circ}$ inv. 71.1911.21.369). Otras estatuillas son más realistas pero de factura igualmente grosera, como por ejemplo la figura masculina de la colección Grandidier (n. ${ }^{\circ}$ inv. 71.1887.129.10). Sus aleaciones contienen zinc y son típicas del período poscolonial (cuadro 5).

Cuadro 5 - Resultado del análisis por FRX de las estatuillas de factura tardía de las colecciones del musée du quai Branly - Jacques Chirac (MQB) y del Ethnologisches Museum de Berlín (EMB)

\begin{tabular}{|l|ccccc|}
\hline \multicolumn{1}{|c|}{ n. ${ }^{\circ}$ inv. } & Ag $\%$ & Cu $\%$ & Zn \% & Pb \% & Sn \% \\
\hline MQB 71.1911.21.369 & & 78,7 & 18,6 & 2,3 & 0,4 \\
MQB 71.1887.129.10 & 55,2 & 40,0 & 3,7 & 0,8 & 0,3 \\
MQB 71.1887.114.87 & 73,6 & 25,8 & & 0,2 & 0,4 \\
MQB 71.1878.2.298.1 & 63,4 & 36,6 & & & \\
EMB 8928 & 52,3 & 47,7 & & & \\
EMB 8927 & 56,0 & 44,0 & & & \\
\hline
\end{tabular}

La estatuilla femenina de la colección Lemoyne (n. inv. 71.1887.114.87), de bordes redondeados y un acabado con detalles anatómicos curvilíneos realizados por incisión, representa a otra serie de piezas conservadas en las colecciones públicas. Sus características formales la distinguen claramente de las producciones incas. La aleación de esta estatuilla no presenta zinc (cuadro 5), sino un alto porcentaje de plata.

Esta serie de estatuillas atípicas está inspirada en el canon inca, tanto en la postura y la actitud de los personajes como en su tocado. Es difícil afirmar que fueron realizadas para lucrar en un mercado peruano de antigüedades en plena expansión (Gänger, 2014a) o si estas piezas fueron destinadas a otro uso. 
Probablemente sea este el caso de la estatuilla maciza de la colección Wiener (n. ${ }^{\circ}$ inv. 71.1878.2.298.1-2; fig. 5), recolectada en una cueva e identificada como una producción inca. El personaje central está sentado, se le representa desnudo con los brazos flexionados y las manos sobre el rostro, tiene una actitud muy diferente a la de las estatuillas incas. Si se le mira de perfil, se observa una joroba en la espalda. Estas características se encuentran en otros ejemplares conocidos: una estatuilla masculina, que forma parte de una pareja, procedente de la colección de María Ana Centeno 23 en Cuzco, hoy conservada en el Ethnologisches Museum de Berlín (n. inv. V A 8928), así como un ejemplar del Museo Histórico de Rosario, en Argentina (Taullard, 1986: fig. 10). Se trata, por lo tanto, de una producción estandarizada que además integra estatuillas de mujeres con la espalda jorobada y el pelo sobre los hombros y la espalda. Estas parecen aludir a la fertilidad, puesto que se representaron ya sea embarazadas (Ethnologisches Museum de Berlín, n. inv. V A 8927) o con actitud de parturienta y el sexo muy dilatado (Taullard, 1986: fig. 12).

El análisis por FRX de la superficie de los ejemplares de estatuillas de París y Berlín muestra la utilización de una aleación plata-cobre similar, que contiene altos porcentajes de cobre (recordemos que esta técnica solo analiza la superficie de los objetos) ${ }^{24}$.

Por lo tanto, estas piezas corresponden a una producción estandarizada que parece haberse concentrado en la región de Cuzco, como lo indican los lugares de recolección de los diferentes ejemplares inventariados. Al parecer, estas piezas son numerosas en las colecciones privadas de Perú y forman parte de una producción popular que se desarrolló en la segunda mitad del siglo XIX25.

\section{CONCLUSIONES}

El estudio de la colección de las estatuillas incas, o de influencia inca, del musée du quai Branly - Jacques Chirac — revelador de la variedad que existe en las colecciones públicas y privadas - refleja una gama de producciones extremadamente variada. Junto a las piezas características de estilo inca, como la estatuilla de hombre o de llama de la colección Fidel López (n.ํinv. 71.1887.130.2, 71.1887.130.3; figs. 3 y 4), cuyas técnicas de elaboración por martillado y soldadura fueron corroboradas por estudios anteriores (Mostny, ed., 1957; Schuler-Schömig, 1981; Rowe, 1996; Bárcena, 2004), se observan ejemplares que han sido influenciados por esta producción orfebre inca «clásica» y, a su vez, se distinguen notablemente. Es el caso de la estatuilla de la colección Lemoyne (n. ${ }^{\circ}$ inv. 71.1887 .114 .90 , fig. 2), que respeta los cánones incas pero acusa divergencias iconográficas y tecnológicas

\footnotetext{
23 Para mayor información sobre esta colección referirse a Gänger (2014b).

${ }^{24}$ Queda pendiente el análisis de la composición de la estatuilla del ciervo (n. ${ }^{\circ}$ inv. 71.1878.2.356) hallada en el mismo contexto que el grupo de los tres personajes.

${ }^{25}$ Luis Repetto Málaga, Museo de Arte y Tradiciones Populares-Instituto Riva-Agüero, Lima, comunicación personal, 2015.
} 
importantes. Si la existencia de la pátina oscura en la superficie dejaba pensar que su fecha de fabricación era relativamente reciente, fue el estudio tecnológico de la pieza lo que permitió poner en evidencia una elaboración conforme a la práctica inca. Estos elementos sugieren que si bien la pieza no es de factura inca imperial, de todos modos parece responder más a una factura indígena. La aleación noble empleada en su fabricación (plata casi pura; sin embargo el análisis fue superficial y de esta manera los valores obtenidos deben corresponder más a la composición de la pátina que a la composición del sustrato) podría provenir de una elección de naturaleza simbólica, de un cómodo acceso a esta materia prima (antes del año 1800) o de ambas. En el caso de esta estatuilla, se puede proponer una fecha de producción comprendida entre la conquista española del siglo XVI y el período republicano. Cabe notar que entre las pocas estatuillas antropomorfas de plata analizadas hasta el día de hoy, las que por su aleación y sus diferencias iconográficas podrían pertenecer al Ilamado período de «transición» (siglo XVI), no han sido patinadas y algunas veces fueron fabricadas con aleaciones más pobres en plata (Vetter Parodi \& Guerra, en este volumen). La pieza podría corresponder entonces a una producción del siglo XVII o ser posterior a ese. De ser así, quedaría por determinar cuál fue el uso que se atribuyó a estas estatuillas en el período colonial luego de la desintegración del aparato estatal inca. Finalmente, las soldaduras restantes corresponderían a restauraciones realizadas en el siglo XIX.

La estatuilla masculina (n. inv. 71.1887.135.8; fig. 1) que muestra a un personaje con cinco mazorcas de maíz se distingue netamente de las estatuillas incas por su iconografía, forma y fabricación. Esta estatuilla corresponde a un tipo de fabricación estandarizada que se caracteriza —en su mayoría - por aleaciones con alto porcentaje de plata y una baja calidad de fundición. Numerosos ejemplares similares han sido inventariados en las colecciones públicas. Otras estatuillas de cánones similares ponen en escena a hombres y mujeres con actitudes diversas. La mayoría de estas piezas posee un orificio en la parte superior de la cabeza y presenta rastros de abrasión que pueden atribuirse a la fricción. En el estado actual de los conocimientos, este grupo homogéneo que posee un estilo o una iconografía que remiten a producciones chimús (1350-1475) o chimú-incas (1475-1532) parecería estar vinculado a las producciones de la costa norte del Perú. Si esta hipótesis es correcta, el ejemplar hallado en Ica (costa sur del Perú) correspondería a un objeto de importación. Sin embargo, el corpus de estatuillas inventariado al día de hoy es muy acotado para comprender la función y, sobre todo, conocer la extensión de esta producción: ¿Se trataba de modelos reproducidos en varios ejemplares, como lo deja suponer la recurrencia del personaje masculino con mazorcas de maíz? ¿O bien esas piezas podían responder a encargos específicos, como parece sugerirlo la variedad de las otras estatuillas con actitudes diversas, inventariadas en las colecciones públicas? De cualquier modo, la mayoría de estas estatuillas parece haber sido destinada a ser sujetada mediante el orificio en la parte superior de la cabeza (incluso, a ser portadas). Esto sugiere, por lo tanto, un uso diferente al de las estatuillas incas votivas y alude a una producción local (¿costa norte del Perú?) probablemente durante el período de influencia inca en el Horizonte Tardío (1476-1532). 
La última categoría de estatuillas mencionada en este artículo reúne un conjunto de producciones muy distintas, de iconografía inca bastante atípica y manufacturadas con aleaciones muy diferentes a las que se observan durante el período inca. Estas piezas han sido realizadas por fundición, la mayoría en bronce, con algunas aleaciones que contienen zinc, metal empleado exclusivamente después de la conquista española26. A menudo de factura grosera, presentan bordes y formas más redondeadas. De una gran variedad desde el punto de vista formal, aparentemente corresponden a producciones tardías, en algunos casos seguramente datan de finales del siglo XIX. Algunas piezas son probablemente falsas; otras, por el contrario, corresponden a producciones originales. La noción de falsificación debe utilizarse con precaución (Bruhns \& Kelker, 2010): por una parte, las reinterpretaciones y las copias también existieron en períodos antiguos y, por otra parte, los objetos que hoy se consideran dudosos no siempre fueron producidos para engañar (Mongne, 2010)27. Algunas estatuillas que seguían la línea de una producción inca reinterpretada pudieron conocer un uso doméstico o ritual, como las del grupo (n. ${ }^{\circ}$ inv. 71.1878.2.298.1-2; fig. 5) hallado por Wiener en una cueva, en las inmediaciones de Cuzco, que contenía estatuillas aparentemente depositadas por unos lugareños como ofrendas. La figura central presenta las mismas características que una pieza metálica conservada en el Museo Arqueológico de la Universidad Nacional de San Antonio Abad en Cuzco (Inv. 89), a saber: la desnudez, la espalda con joroba y la posición en cuclillas. Atribuida a la cultura inca, esta última tiene un tamaño inferior $(6,5 \mathrm{~cm}$ de altura) y fue realizada por fundición con una «aleación a base de cobre con alto porcentaje de estaño» (Stéfani, 1992: fig. 90).

En el pasado, este personaje fue interpretado como una representación del ekeko, una entidad aimara que aún hoy en los Andes está asociada a la prosperidad (Querejazu Lewis, 1983: fig. 144). La pieza recolectada por Wiener podría estar inspirada en modelos tradicionales y, tal vez, prehispánicos, aludiendo a creencias vigentes durante su estadía.

El corpus de estatuillas metálicas incas aunado al del período de dominación inca o de forma y/o técnicas de influencia inca es particularmente vasto en sus formas, aleaciones y técnicas. La publicación parcial de este corpus, que a menudo deja de lado las piezas atípicas o las que plantean problemas, hace más complejo el estudio y la comprensión de esta producción. En particular, la ausencia de una tipología completa de estas formas y la escasez de análisis físico-químicos y de tecnologías de conjuntos completos dificulta la comprensión de la evolución de esta producción en el espacio (variedad de producciones en el Tahuantinsuyo) y en el tiempo (producciones incas, coloniales y modernas). Análisis exhaustivos acerca de otros corpus museísticos y piezas halladas en contexto permitirán precisar las hipótesis presentadas en este artículo.

26 Algunos objetos prehispánicos, en particular los de base cobre del noroeste argentino, contienen zinc, en concentraciones normalmente inferiores a 10\% (véase por ejemplo Cabanillas \& González, 2012).

27 El papel del análisis físico-químico en el caso de falsificaciones fue tratado en Guerra (2008b). 


\section{Agradecimientos}

Agradecemos especialmente a Luis Enrique Castillo (MNAAHP de Lima) y a Manuela Fischer (Ethnologisches Museum de Berlín) por su ayuda y por el acceso privilegiado que nos brindaron a las colecciones que tienen a su cargo. Nuestro reconocimiento, asimismo, a Dominique Robcis por su contribución al análisis de las colecciones del musée du quai Branly - Jacques Chirac (análisis FRX realizados en París) y a Juan Apunte de Symtek (Niton, Perú) por el préstamo del equipo FRX y por los análisis efectuados en el MNAAHP en Lima. Deseamos agradecer también a Ann Pollard Rowe, Luis Repetto Málaga y Helena Horta Tricallotis por sus indicaciones y comentarios; al evaluador anónimo de este artículo por sus observaciones sobre la primera versión del texto y a la traductora Julia Azaretto.

\section{Referencias citadas}

\section{Archivos}

\section{Catálogo del musée d'ethnographie du Trocadéro}

Archivos del musée de l'Homme, «Serie N, inventarios», subserie «N.1, MH-Laboratoire d'ethnologie» (referencia de los documentos digitalizados en el musée du quai Branly - Jacques Chirac)

- Inventario de colecciones del musée d'ethnographie du Trocadéro del N. ${ }^{\circ} 1$ al 5599, D000558

N. ${ }^{\circ}$ de registro 4056, D000558/28622

- Catálogo N. 12 del N. ${ }^{\circ} 19001$ al 21500, D000552

N. ${ }^{\circ}$ de registro 20039, D000552/28797

N. ${ }^{\circ}$ de registro $21114-21117$ Y 21119 , D000552/28824

N. ${ }^{\circ}$ de registro 21291, D000552/28829

N. ${ }^{\circ}$ de registro del 21329 al 21332, D000552/28830

\section{Registro de inventario de la colección Berthon (71.1911.21, Perú)}

Archivos del musée du quai Branly - Jacques Chirac, D003370

N. ${ }^{\circ}$ de registro 11.21 .368 y 11.21 .369$, D003370/44478

N. ${ }^{\circ}$ de registro 11.21.476, D003370/44482

\section{Fuentes publicadas}

BAESSLER, A., 1904 - Altperuanische Metallgeräte, nach seinen Sammulungen von Arthur Baessler, vi + 142 pp.; Berlín: A. Asher.

BÁRCENA, R., 2004 - Las piezas metálicas de la ofrenda ritual del Cerro Aconcagua, Mendoza, República Argentina. Anejos de Archivo Español de Arqueología, 32: 157-172. 
BERTHON, P., 1911 - Étude sur le précolombien du bas-Pérou, 76 pp.; París: Imprimerie nationale.

BIRD, J., 1979 - Legacy of the stingless bee. Natural History, 88 (9): 49-51.

BRAY, W., 1990 - Le travail du métal dans le Pérou préhispanique. In: Inca-Perú : 3000 ans d'histoire (S. Purini, ed.): 292-315; Bruselas: Musées royaux d'art et d'histoire.

BRUHNS, K. O. \& KELKER, N. L., 2010 - Faking the Ancient Andes, 220 pp.; California: Left Coast Press.

BURGER, R. L. \& SALAZAR, L. C., 2004 - Machu Picchu: unveiling the mystery of the Incas, viii + 230 pp.; New Haven, Londres: Yale University Press.

CABANILLAS, E. D. \& GONZÁLEZ, L. R., 2012 - Aleaciones y estilo en épocas de contacto hispano-indígena en el noroeste argentino. Revista de Arqueología Histórica Argentina y Latinoamericana, 6: 185-198.

CASTELNAU, F. de, 1852 - Expédition dans les parties centrales de l'Amérique du Sud: de Rio de Janeiro à Lima, et de Lima au Pará ; exécutée par ordre du gouvernement français pendant les années 1843 à 1847, sous la direction de Francis de Castelnau. Troisième partie : Antiquités des Incas et autres peuples anciens; París: P. Bertrand.

CASTRO, I. de \& KURELLA, D. (eds.), 2013 - Inka: Könige der Anden, 347 pp.; Darmstadt: Verlag Philipp Von Zabern.

CUMMINS, T., 2015 - Queros, Aquillas, Uncus, and Chulpas: The Composition of Inka Artistic Expression and Power. In: Variations in the Expression of Inka Power (R. L. Burger, C. Morris \& R. Matos Mendieta, eds.): 267-311; Washington, D. C.: Dumbarton Oaks Research Library and Collection.

DRANSART, P., 1995 - Elemental Meanings: Symbolic Expression in Inka miniature Figurines, 58 pp.; Londres: Institute of Latin American Studies, University of London.

DRANSART, P., 2000 - Clothed Metal and the Iconography of Human Form among the Incas. In: Precolumbian Gold: Technology, Style and Iconography (C. McEwan, ed.): 76-91; Londres: British Museum Press.

DUVIOLS, P., 1976 - La Capacocha. Allpanchis, 9: 11-57.

EMMERICH, A., 1965 - Sweat of the Sun and Tears of the Moon: Gold and Silver in PreColumbian Art, xxiii + 216 pp.; Seattle: University of Washington Press.

GÄNGER, S., 2014a - Relics from the Past. The Collecting and Study of Pre-Columbian Antiquities in Peru and Chile, 1837-1911, xiii + 311 pp.; Nueva York: Oxford University Press.

GÄNGER, S., 2014b - The Many Natures of Antiquities: Ana María Centeno and Her Cabinet of Curiosities, Peru, ca. 1832-1874. In: Nature and antiquities: the making of archaeology in the Americas (P. L. Kohl, I. Podgorny \& S. Gänger, eds.): 110-124; Tucson: University of Arizona Press.

GUERRA, M. F., 2008a - An Overview on the Ancient Goldsmith's Skill and the Circulation of Gold in the Past: the Role of X-ray based Techniques. X-ray Spectrometry, 37 (4): 317-327.

GUERRA, M. F., 2008b - Archaeometry and museum: fifty years of curiosity and wonder. Archaeometry, 50 (6): 951-967.

GUIMARÃES, S., 1994 - Les anciennes collections précolombiennes au Louvre. Le musée des antiquités américaines de A. de Longpérier; París: École du Louvre. Mémoire de 2 e Cycle.

HAMY, E.-T., 1897 - Galerie américaine du musée d'ethnographie du Trocadéro : choix de pièces archéologiques et ethnographiques, ii + 118 pp.; París: Musée d'ethnographie du Trocadéro. 
HEYERDAHL, T., SANDWEISS, D. H. \& NARVÁEZ, A., 1995 - Pyramids of Túcume: the quest for Peru's forgotten city, 240 pp.; Nueva York: Thames and Hudson.

HUGHES, R., 1993 - Artificial Patination. In: Metal Plating and Patination: Cultural, Technical and Historical Developments (S. La Niece \& P. Craddock, eds.): 1-18; Londres: Butterworth-Heinemann Ltd.

ITIER, C., 2008 - Les Incas, 214 pp.; París: Les Belles Lettres.

JONES, J., 1964 - Art of the Empire: The Inca of Peru, 56 pp.; Nueva York: Museum of Primitive Art.

KING, H., 2000 - Rain of the Moon. Silver from Ancient Peru, 64 pp.; Nueva York: The Metropolitan Museum of Art, Yale University Press.

LAPINER, A., 1976 - Pre-Columbian Art of South America, 460 pp.; Nueva York: Harry N. Abrams, Inc.

LECHTMAN, H., 1988 - Traditions and Styles in Central Andean Metalworking. In: The Beginning of the Use of Metals and Alloys (R. Maddin, ed.): 344-378; Massachusetts: Massachusetts Institute of Technology Press.

LEVENSON, J. A. (ed.), 1991 - Circa 1492: Art in the Age of Exploration, 671 pp.; Washington, D. C., New Haven: National Gallery of Art, Yale University Press.

McEWAN, C. \& VAN DE GUCHTE, M., 1992 - Ancestral Time and Sacred Space in Inca State Ritual. In: The Ancient Americas: Art from Sacred Landscapes (R. F. Townsend, ed.): 359-371; Chicago: Art Institute of Chicago.

MIGNONE, P., 2015 - Illas y allicac. La capacocha del Llullaillaco y los mecanismos de ascenso social de los "Inkas de privilegio". Boletín del Museo Chileno de Arte Precolombino, 20 (2): 69-87.

MONGNE, P., 2010 - Du Golgotha au tzompantli. Les crânes « aztèques » en cristal de roche. Gradhiva, 11: 181-187.

MOSTNY, G. (ed.), 1957 - La momia del Cerro El Plomo. Boletín del Museo Nacional de Historia Natural, 27: 1-119.

NÚÑEZ-REGUEIRO, P. (ed.), 2015 - L'Inca et le Conquistador, 200 pp.; París: musée du quai Branly, Actes Sud.

OBERHAUSER, F. \& FUHRMANN, P., 1957-1959 - Estudio metalúrgico. In: La momia del Cerro El Plomo (G. Mostny, ed.): 78-81; Santiago de Chile: Boletín del Museo Nacional de Historia Natural, vol. 27.

QUEREJAZU LEWIS, R., 1983 - El Ekeko, diosecillo tutelar predilecto de los aimaras. In: EI mundo arqueológico del Cnl. Federico Diez de Medina (R. Querejazu Lewis, ed.): 139-146; La Paz: Editorial Los Amigos del Libro.

REINHARD, J. \& CERUTI, M. C., 2010 - Inca Rituals and Sacred Mountains: A Study of the World's Highest Archaeological Sites, xvi + 264 pp.; Los Ángeles: Cotsen Institute of Archaeology Press, University of California.

RIVET, P. \& ARSANDAUX, H., 1946 - La métallurgie en Amérique précolombienne, 254 pp.; París: Institut d'Ethnologie.

RIVIALE, P., 1996 - Un siècle d'archéologie française au Pérou (1821-1914), 425 pp.; París: L'Harmattan.

ROVIRA LLORÉNS, S., 1990 - La metalurgia americana: análisis tecnológico de materiales prehispánicos y coloniales, xi + 1049 pp.; Madrid: Editorial de la Universidad Complutense de Madrid, Servicio de Reprografía.

ROVIRA LLORÉNS, S. \& GÓMEZ RAMOS, P., 1995 - Los objetos de metal de la colección Juan Larrea: un estudio arqueometalúrgico. Anales del Museo de América, 3: 21-33. 
ROWE, A., 1984 - Costumes and Featherwork of the Lords of Chimor: Textiles from Peru's North Coast, 190 pp.; Washington, D. C.: The Textile Museum.

ROWE, J. H., 1996 - Inca. In: Andean Art at Dumbarton Oaks (E. H. Boone, ed.): 301-320; Washington, D. C.: Dumbarton Oaks Research Library and Collection.

RUDOE, R., 1993 - Oxidized Silver in the 19th Century: the Documentary Evidence. In: Metal Plating and Patination: Cultural, Technical and Historical Developments (S. La Niece \& P. Craddock, eds.): 161-170; Londres: Butterworth-Heinemann Ltd.

SCHOBINGER, J. (ed.), 2001 - El santuario incaico del cerro Aconcagua, 453 pp.; Mendoza: Editorial de la Universidad Nacional de Cuyo.

SCHULER-SCHÖMIG, I. von, 1981 - Werke indianischer Goldschmiedekunst, 43 pp.; Berlín: Staatliche Museen, Preußischer Kulturbesitz.

STÉFANI, C., 1992 - Figurine d'homme bossu. In: L'art des Incas dans les collections des Musées de Cusco: 156; Chartres: Musée de Chartres.

TAULLARD, A., 1986 - Platería sudamericana, 282 pp.; Buenos Aires: M. C. Leloir.

TROALEN, L. G. \& GUERRA, M. F., 2016 - Gold from the tomb of Scribe Beri: a comparative analytical approach to the New Kingdom gold grave goods from Riqqa (Egypt). Applied Physics A: Materials, Science \& Processing, 122 (3): 1-12.

WIENER, C., 2010 [1880] - Voyage au Pérou et en Bolivie (1875-1877), 464 pp.; París: Ginkgo éditeur. 